\title{
Grzegorz PIWNICKI
}

DOI : $10.14746 / \mathrm{pp} .2016 .21 .1 .7$

Gdańsk

\section{Dylematy wprowadzenia euro w Polsce przez pryzmat polityczny i gospodarczy}

\begin{abstract}
Streszczenie: Problem przystapienia Polski do strefy euro jest ponadczasowy, ważny nie tylko w kwestiach gospodarczych i politycznych, ale przede wszystkim cywilizacyjnych. Nasz kraj po upadku komunizmu opowiedział się za włączeniem do struktur europejskich (NATO i Unia Europejska). Była w tym wyborze zgoda elit politycznych, podporządkowano temu całą polską politykę wewnętrzną i zagraniczną. Cel został osiagnięty w latach 1999-2004. Wydawać by się mogło, że po osiagnięciu tego sukcesu państwo polskie dalej będzie się integrować z Zachodem, wpisywać się w krąg cywilizacji zachodnioeuropejskiej. To jedyna droga wyjścia z peryferii i zajęcia miejsca w centrum Europy i zachodniej cywilizacji, do czego Polska dążyła bezskutecznie przez kilkaset lat. Tymczasem okazało się, że większość elit politycznych z koniunkturalnych i doraźnych pobudek zmieniła w tej fundamentalnej sprawie zdanie. Jest to bardzo niebezpieczny trend polityczny, ponieważ możemy być w najbliższej przyszłości jako państwo, ale również społeczeństwo zmarginalizowani jako peryferie w przestrzeni europejskiej. Euro to nie tylko wspólna waluta, ale gwarant stałego miejsca w centrum Europy co mogłoby zapewnić Polsce bezpieczny byt, stabilność gospodarczą obecnie i w przyszłości, wyzwolenie się od przeszłości wschodnioeuropejskiej.
\end{abstract}

Słowa kluczowe: euro, struktury europejskie, centra i peryferie, twardy rdzeń Europy, cywilizacja zachodnioeuropejska

$\mathbf{P}$ olska, podejmując starania o przyjęcie do Unii Europejskiej, zobowiązała się, po tej akcesji do przyjęcia wspólnej waluty euro (Mucha-Leszko, 2007). Jednolity pieniądz jest miernikiem poziomu integracji europejskiej i początkiem nie tylko unii gospodarczej, ale i politycznej. Ekskluzywny klub bogatych państw Europy Zachodniej zdecydował po 1989 r. o przyjęciu do swego grona państw Europy Środkowo-Wschodniej, które nie skorzystały z cudu gospodarczego po II wojnie światowej i odstawały od niego ekonomicznie i cywilizacyjnie. Może się to przyczynić do wyrównania poziomów dobrobytu między obu członami Europy w perspektywie 20-40 lat po zjednoczeniu. Unia poprzez powiększenie swojego obszaru ekonomicznego, politycznego i demograficznego może zbudować państwo federacyjne na wzór Stanów Zjednoczonych i skutecznie konkurować w drugiej połowie XXI wieku z potęgą CHRL i USA w skali globalnej. Jednym z podstawowych warunków tego sukcesu jest wspólna waluta całego obszaru Unii Europejskiej (Okręziak, 2008).

W wymiarze politycznym głównym celem jest zminimalizowanie egoizmów narodowych państw Unii, poparcia dla tych planów społeczeństw, eliminowania z życia politycznego skrajnych ruchów politycznych (neofaszystowskich, ultra narodowych, ultralewicowych itd.) metodami perswazji i obnażania skutków politycznych rządów ekstremistów. Do tej wizji należy zbudować szeroki front społecznego poparcia narodów europejskich i szybko wykształcić elity polityczne zdolne do tych wyzwań. 
Głównym elementem powinno być możliwe najpełniejsze zintegrowanie Polski z cywilizacją zachodnioeuropejską oraz wyjście z peryferii i zakotwiczenia się w centrum Europy. Pisał o tym Immanuel Wallerstein (Wallerstein, 2007).

\section{Dylematy polityczne przystąpienia Polski do strefy euro}

Problemy zarysowane przez Imanuella Wallersteina to wyzwanie dla polskiej klasy politycznej, tej rządzącej i tej w opozycji. Elity są bezpośrednio odpowiedzialne za przyszłość państwa i społeczeństwa. W XXI wieku największym wyzwaniem dla Polski jest integracja z zachodnią Europa - czyli centrum kontynentu, idzie o to, aby zająć w niej miejsce podmiotu, a nie przedmiotu. Kraje postkomunistyczne powinny zbudować w Unii wspólny front polityczno-ekonomiczny, aby móc za kilkadziesiąt lat być nowoczesnymi w miarę zasobnymi demokracjami o ustabilizowanej pozycji w centrum, a nie na orbicie peryferyjnej entej-prędkości. Jak w soczewce problem ten ogniskuje się w kwestii przystąpienia do strefy walutowej euro (Przybylska-Kapuścińska, 2008). Jest to zadanie priorytetowe, aktualne rządy od 2007 r. zapowiadają przyjęcie wspólnej waluty, przesuwając terminy do bliżej nieokreślonej przyszłości. Podnosi się sprawę przystosowania konkurencji polskiej gospodarki, reform, abyśmy byli jako państwo dobrze przygotowani. Zapomina się, że minęło już 25 lat od zmiany systemu polityczno-gospodarczego, dalej jesteśmy na etapie transformacji. W tym roku, 1 maja, minie 10 lat od wstapienia do Unii Europejskiej. Europa nam ucieka, a reform przystosowawczych nie widać. $\mathrm{W}$ takim tempie reformowania kraju minie kolejne kilkadziesiąt lat, a dołączenie do centrum oddala się.

8 listopada 2011 r. ówczesny prezydent Francji Nicolas Sarkozy wezwał do stworzenia Europy dwóch prędkości: „federalnego” rdzenia złożonego z 17 członków strefy euro i z luźniejszym „konfederacyjnym” zewnętrznym pasem dziesięciu państw członkowskich spoza strefy euro. Stwierdził m.in. „Nie można mieć wspólnej waluty bez konwergencji i integracji gospodarczej. To niemożliwe. $Z$ drugiej strony, nie można apelować o federalizm, a jednocześnie o poszerzenie Europy. To niemożliwe! Tu jest sprzeczność. Jest nas 27 państw. Będziemy oczywiście musieli otworzyć się na Bałkany. Będzie nas 32 lub 34. Nie wyobrażam sobie, że ktokolwiek myśli, że federalizm - pełna integracja - jest możliwy. Nie będzie wspólnej waluty bez większej integracji gospodarczej i konwergencji. To pewne. I to jest kierunek, w którym zmierzamy. Czy 27 krajów muszą obowiązywać te same reguły? Nie. Absolutnie. [...] Ostatecznie, będą dwa biegi europejskie: pierwszy w kierunku integracji w sferze euro i drugi, który jest bardziej konfederacyjny w Unii" (Europa dwóch prędkości czy dwie Europy, „The Economist”, 10 listopada 2011 r.).

Chociaż 9 listopada 2011 r. przewodniczący Komisji Europejskiej Jose Manuel Barroso zganił za taki pogląd prezydenta Nicolasa Sarkozy'ego, to wkrótce po tym Joschka Fiszer powiedział niemieckiemu tygodnikowi „Die Zeit”, że Unia przy 27 krajach stała się organem niewydolnym. To co prezentują w swoich wystąpieniach i poglądach były prezydent Francji Nicolas Sarkozy i były minister spraw zagranicznych Niemiec Joschka Fiszer jest niczym innym jako potwierdzeniem „zdrowego rdzenia” Europy, czyli jego centrum i pozostałych państw, czyli peryferii. To determinuje czarny scenariusz przyszłości Unii Europejskiej. 
Angela Merkel ma dwa różne oblicza: dla Niemców i dla reszty Europy - pisze niemiecki socjolog Ulrich Beck, przed wyborami federalnymi we wrześniu 2013 r.

Od początku kryzysu upadło wiele rządów w Europie. Niemieckiej kanclerz to jednak nie grozi. Rodacy kochają Angelę Merkel przede wszystkim dlatego, że tak mało od nich wymaga. I dlatego, że preferuje nowy w Europie sposób uprawiania polityki: merkiawelizm. Niccolo Machiavelli pisze w Księciu: „trzeba, by ludzie kochali władcę i bali się go jednocześnie". W merkiawelizmie używa się tej zasady selektywnie. Za granicą Merkel budzi strach, ale w kraju jest kochana właśnie za to, że inne narody boją się Niemców. Brutalny neoliberalizm dla świata zewnętrznego, akceptacja dla socjaldemokratycznych idei w kraju - to zwycięski przepis, który pozwala Merkel wciąż wzmacniać pozycję Niemiec i jej samej.

Mamy rzadki przypadek konsensu: dwie partie opozycyjne, socjaldemokraci z SPD i Zieloni, atakują rządową politykę oszczędności w szczegółach, ale w parlamencie głosowały ostatecznie za cięciami. Z drugiej strony dwie partie, które wraz z CDU tworzą koalicję rządząca, czyli bawarska CSU i liberałowie z FDP, są zaskakująco daleko od stanowiska własnego rządu. Jednak w rezultacie debata o europejskim kryzysie w niemieckim parlamencie była jednostronna, bo Merkel zabrakło przeciwników.

Teraz Berlin, w nowej fazie europejskiego kryzysu, staje przed historyczną decyzją. Albo spróbuje ożywić marzenie o wspólnej politycznej Europie, albo będzie kontynuować pogmatwaną politykę, w której powstrzymywanie się od decyzji jest środkiem nacisku (Beck, 2013).

W styczniu-lutym 2014 r. w „Foreign Affairs” ukazał się artykuł profesora i kierownika katedry nauk politycznych Northeostern University w Bostonie Mitchella A. Orensteina, w którym opisano aktualną sytuację Polski.

To, że Polska jest dzisiaj tak dobrym miejscem do inwestowania, w części wynika z głębokich więzi, jakie połączyły ją z czołową gospodarką europejską. Ważna część machiny eksportowej Niemiec jest dziś zlokalizowana w Polsce. Polska korzysta z niemieckich inwestycji i dostępu do niemieckich rynków, a Niemcy, dzięki temu, że koszty są w Polsce niskie, a kwalifikacje pracowników wysokie, traktują ją jako platformę produkcyjna, żeby konkurować z Azją Wschodnią. Niektóre gałęzie niemieckiego przemysłu potrafią wytwarzać w Polsce towary taniej, niż gdyby robiono to w Chinach. A Polska oferuje Niemcom przyjazny klimat biznesowy, mnóstwo wykwalifikowanej siły roboczej i nade wszystko bliskość geograficzną.

Niemcy znaczną część powodzenia przemysłu motoryzacyjnego zawdzięczają właśnie Polsce. W Poznaniu Volkswagen zatrudnia 6,9 tys. robotników wytwarzających moduły zasilania, głowice cylindrów i obudowy układów kierowniczych, a także 155 tys. samochodów dostawczych.

Grupa MAN zatrudnia w Polsce 4 tys. ludzi wytwarzających ciężarówki, autobusy miejskie i karoserie. Samochody i części są ważnym towarem eksportowym Polski, choć nie ma ona żadnej własnej marki o międzynarodowej renomie; znaczna część tych wyrobów pojawia się na rynku pod markami niemieckimi. Podobnie jest w innych gałęziach przemysłu - np. niemiecki dom mody Hugo Boss produkuje obuwie w swojej fabryce w Radomiu.

Ze względu na to, że Polska jest ważnym elementem niemieckiego łańcucha dostaw, stała się wielką gospodarką produkującą na eksport - dzisiaj to $46 \%$ jej PKB. W spra- 
wozdaniu banku Morgan Stanley szacowano, że 30-40\% eksportu Polski do Niemiec trafia do reszty świata jako towary eksportowe przez Niemcy. Wyjaśnia to, dlaczego Niemcy są największym partnerem handlowym Polski - kupują lub sprzedają 25\% towarów przez nią eksportowanych i importowanych.

$Z$ uwagi na decydujące znaczenie inwestycji zagraniczny dla polskiej gospodarki, na stopień jej uzależnienia od handlu zagranicznego i to, że wielu Polaków pracuje za granicą specjaliści od ekonomii politycznej często określają Polskę jako „zależną gospodarkę rynkową". Ta zależność prowadzi do zasadniczego dylematu: aby przyciagać zagraniczne firmy i zachować konkurencyjność, Polska musi utrzymywać niski poziom wynagrodzeń, wynoszący dzisiaj około jednej trzeciej poziomu, który mają bardziej rozwinięte kraje Unii ${ }^{1}$. Jednak wielu Polaków zna te kraje i pracuje w nich, więc aspiruje do wyższego poziomu życia. To utrudni Polsce czerpanie korzyści wynikających z taniej siły roboczej.

Polska powinna mieć na uwadze ten dylemat, gdyż w jej pobliżu znajdują się inne kraje, które mogłyby posłużyć jako baza produkcyjna. Kiedy w 2009 r. Dell przeniósł europejską fabrykę z Limerick w Irlandii do Lodzi, burmistrz Limerick złośliwie zapowiadał, że Dell zapewne za kilka lat przeniesie się na Ukrainę. Można by to samo powiedzieć o wielu call centre, centrach obsługi telefonicznej, które stały się filarami zatrudnienia w kraju.

Polska musi zatem wznieść się wyżej i przystapić do produkowania większej ilości towarów na eksport powstałych z udziałem najnowocześniejszej myśli technicznej. Dziś w badania i rozwój inwestuje niewiele w porównaniu z bardziej rozwiniętymi sąsiadami - ledwie $0,7 \%$ PKB, podczas gdy w całej Unii ta wartość wynosi ok. $2 \%$.

Jednak największym długoterminowym zagrożeniem dla Polski byłby zbyt szybki wzrost spożycia i wynagrodzeń, co hamowałoby inwestycje wewnętrzne i odstraszało firmy zagraniczne. Zarządzając rozwojem kraju, polscy politycy muszą chodzić po linie, z jednej strony zaspokajając wymagania wyborców, z drugiej utrzymując niskie wynagrodzenia.

Ten dylemat wyjaśnia, dlaczego - przynajmniej w bliskiej przyszłości - Polska zapewne nie przystapi do strefy euro. Zdołała przetrwać kryzys z 2008 r. częściowo dlatego, że mogła zdewaluować złotego, co przyczyniło się do utrzymania eksportu zachowania miejsc pracy w kraju. A kiedy w 2009 r. nastąpił kryzys zadłużenia państwo dzięki dewaluacji i bodźcom rządowym zdołało jako jedyny kraj europejski uniknąć recesji.

Elity biznesowe zdają sobie sprawę $\mathrm{z}$ tego, że utrzymanie własnej waluty oznacza ponoszenie przez inwestorów kosztów transakcyjnych, ale przyczynia się też do utrzymania wynagrodzeń na niskim poziomie. Nie oczekujmy więc, że zobaczymy na ulicach Krakowa czy Gdańska banknoty euro, chyba że poziomy życia w Polsce i w strefie euro znacznie się do siebie zbliżą.

Dla firm zachodnich Polska jest nadal - w porównaniu ze swymi sąsiadami - atrakcyjnym wyborem. Ma 38 mln ludności - w przybliżeniu czterokrotnie więcej niż Czechy czy Węgry - co oznacza, że dysponuje dużym rynkiem wewnętrznym. Znacznie niższe są też w niej koszty wynagrodzeń. W jej strukturach zarządzania w większym stopniu przestrzega się przepisów niż w konkurujących z Polską krajach o niskich płacach, takich jak Bułgaria, Rumunia czy kraje spoza UE.

1 Należy wyraźnie stwierdzić, że Polska i inne kraje Europy Środkowo-Wschodniej faktycznie zintegrują się z Europą Zachodnią tylko wtedy, gdy płace w tej części kontynentu będą minimum na poziomie takich państw jak: Hiszpania, Włochy, a nawet Grecja. 
Pod pewnymi względami Polska odpowiada wzorowi, jaki chciałaby dla Europy stworzyć kanclerz Angela Merkel. Polska wykuła sobie opłacalną niszę w niemieckiej machinie produkcyjnej i może prosperować dzięki nastawionej na eksport gospodarce opartej na silnej walucie i przytłumionym popycie krajowym. Niemiecki model wywołał gniew w Europie Południowej, ale jest skuteczny w Polsce. Z prognoz ekonomicznych wynika, że do 2030 r. polska gospodarka będzie wzrastać średnio o 2,5\% rocznie, stając się jedną z 20 czołowych gospodarek świata, zanim z czasem jej wzrost ulegnie zahamowaniu z powodów demograficznych. Jeżeli jednak zdoła stworzyć bardziej gościnne środowisko biznesowe i gospodarkę opartą na wiedzy, zachęcić do imigracji oraz doprowadzić do wzrostu stopy urodzeń, to może rosnąć jeszcze szybciej (Orenstein, 2014).

\section{Dylemat gospodarczy}

Zaniechanie przyjęcia euro i pozostawienie pieniądza krajowego wcale nie oznacza braku niebezpieczeństwa obniżania się konkurencyjności międzynarodowej. Dokładnie te same mechanizmy, które są odpowiedzialne za przyspieszenie inflacji w kraju członkowskim unii walutowej, dla kraju posługującego się własnym pieniądzem oznaczają presję na nominalną aprecjację kursu walutowego, co było widać w tzw. normalnych, czyli przedkryzysowych, czasach. Alternatywa nie wygląda więc tak: przyjąc euro i utracić konkurencyjność na skutek podwyższenia inflacji czy pozostać przy złotym i zachować konkurencyjność, ale raczej tak: przyjąć euro i zmagać się ze skutkami realnej aprecjacji czy pozostać poza strefą euro i narażać się na nominalną aprecjację kursu walutowego,

Konkurencyjność polskiej gospodarki, czy to w strefie euro, czy poza nią, w dużej mierze będzie określona przez porównanie dynamiki zmian w kursie walutowym (nominalnym lub realnym) i tempa wzrostu wydajności pracy. Co najmniej trzy argumenty przemawiają za tym, że polska gospodarka stosunkowo szybko zwiększać będzie wydajność czynników wytwórczych.

1. Na naszą rzecz działa tzw. efekt doganiania - w kraju o niższym poziomie wydajności tempo przyrostu efektywności jest zwykle wyższe, bo możliwe jest chociażby korzystanie z wdrożeń wynalazków powstałych i sfinansowanych w krajach bogatszych.

2. Struktura polskiej gospodarki cechuje się stosunkowo wysokim udziałem przemysłu w PKB ( $32 \%$ wobec $26 \%$ w strefie euro w 2011 r.). Należy pamiętać, że to w przemyśle dzięki poprawie organizacji i inwestycjom kapitałowym można uzyskiwać wysokie tempo wzrostu wydajności, podczas gdy w sektorze usług jest to raczej trudne.

3. Duże nadzieje powinniśmy wiązać ze środkami z budżetu UE, które Polska uzyskuje w ramach Funduszu Spójności i funduszy strukturalnych. Oczywiście warunkiem koniecznym jest efektywne wykorzystanie środków na poprawę stanu infrastruktury i jakości kapitału ludzkiego, co przekładać się będzie na wysokie tempo zwiększania się wydajności polskiej gospodarki.

Rezygnacja z narodowej waluty znacznie zmniejsza ryzyko kursowe, ale nie likwiduje go całkowicie - problem kursu euro/złoty znika, ale wciąż będziemy musieli śledzić takie kursy, jak: euro/dolar, euro/frank szwajcarski, euro/juan itd. W przypadku naszego eksportu sytuacja jest jasna $-79 \%$ naszych towarów trafia do innych krajów UE, więc 
członkostwo w strefie euro dla zdecydowanej większości przedsiębiorstw eksportowych oznacza wyeliminowanie ryzyka kursowego.

Jeśli chodzi o import, sytuacja jest trochę inna - tutaj nasze obroty z UE to 59\%, co jest wynikiem dużego importu z Rosji - 10,2\% i z Chin - 9,4\% (dane wg GUS). Taka struktura importu ma swoje konsekwencje dla rozkładu ryzyka kursowego. Z Rosją praktycznie całość rozliczeń jest prowadzona w dolarach amerykańskich (walutą dla rynku ropy i gazu jest przede wszystkim dolar); chińskie przedsiębiorstwa także wolą rozliczać się w dolarach, gdyż polityka ich banku centralnego polega na stabilizowaniu kursu juan/dolar. Dla polskiego importu kwestia ryzyka kursowego będzie wynikała $\mathrm{z}$ dwóch zmian, tj. faktycznego zniknięcia ryzyka w handlu ze strefą euro (największy udział w polskim imporcie mają Niemcy $-21,9 \%$ ) oraz ze zmiany ryzyka dolar/złoty na dolar/euro. Jeśli spojrzymy na kursy walut od roku 2004 do dzisiaj, to widać, że dużo większa zmienność występuje w relacji walut dolar/złoty niż dolar/euro. Różnica między najwyższym a najsłabszym kursem złotego w tym okresie wyniosła prawie $60 \%$, podczas gdy w przypadku kursu euro/dolar $-35 \%$.

Podsumowując, nie ma wątpliwości, że wejście do strefy euro zasadniczo zmniejsza ryzyko kursowe dla polskiej gospodarki, a co za tym idzie stanowi wzmocnienie jej konkurencyjności.

Problem nie może być sprowadzony do stwierdzenia, że im niższa stopa procentowa, tym wyższa konkurencyjność danej gospodarki. Kryzys finansowy wyraźnie pokazał, że problemem może być także zbyt niski koszt kapitału, który prowadzi do gwałtownego wzrostu znaczenia dźwigni finansowej, czemu towarzyszy zwykle spekulacyjny wzrost cen aktywów (nieruchomości i instrumentów finansowych), co destabilizuje gospodarkę i zwykle kończy się bolesnym dostosowaniem, czyli kryzysem. Zatem kluczowe są:

1) trwała konwergencja poziomu inflacji i rynkowych stóp procentowych;

2) odpowiednia polityka makroostrożnościowa, tj. stały monitoring i reagowanie nadzoru finansowego na takie przejawy niestabilności, jak zbyt duży zakres dźwigni finansowej, wysoka dynamika cen aktywów czy zbilansowanie sektora bankowego (stosunek depozytów do kredytów) (Tomkiewicz, 2013, s. 3).

Konieczność wypełnienia kryterium inflacyjnego nie powinna być postrzegana jako zagrożenie dla konkurencyjności gospodarki. Byłoby tak, gdyby istniał wymóg szybkiego obniżenia tempa inflacji, co wymagałoby prowadzenia restrykcyjnej polityki pieniężnej, która ograniczałaby zdolności rozwojowe polskiej gospodarki. Jeśli odrzucimy okoliczności wyjątkowe, jakimi byłaby głęboka deflacja w kilku krajach UE, co skutkowałoby istotnym zredukowaniem wartości referencyjnej, to można stwierdzić, że polityka NBP nie wymaga zasadniczej rewizji (zaostrzenia) w stosunku do tego, jak jest prowadzona dzisiaj. Niska, stabilna inflacja jest korzystna dla konkurencyjności gospodarki, więc konieczność wypełnienia kryterium z Maastricht nie powinna oznaczać pogorszenia warunków makroekonomicznych dla funkcjonowania przedsiębiorstw.

Sytuacja stanie się bardziej skomplikowana, gdy będziemy już w systemie ERM II, tj. kurs walutowy musi być utrzymany w ograniczonym paśmie i w tym samym czasie inflacja nie może zwiększyć się poza poziom referencyjny. Dokładnie taki problem wystąpił na Słowacji, która, będąc już w systemie ERM II, musiała dokonać rewaluacji parytetu centralnego, co oznaczało wejście do euro ze stosunkowo mocnym kursem korony, a to wpłynęło negatywnie na konkurencyjność słowackich przedsiębiorstw. Pamię- 
tajmy, że w tym samym czasie (początek roku 2009) złoty mocno się osłabił do euro, więc polska gospodarka znacznie zyskała kosztem Słowacji².

Konieczność utrzymania kursu walutowego w określonym przedziale może rodzić także inne niebezpieczeństwa, takie jak:

1) niemożność absorpcji szoków asymetrycznych przez nominalne zmiany kursu walutowego, gdyż wahania kursu są ograniczone przez reguły systemu ERM II;

2) ryzyko ataku spekulacyjnego - inwestorzy mogą mieć pokusę, żeby przetestować determinację banku centralnego w obronie kursu, a tym samym sporo zarobić kosztem naszych rezerw walutowych;

3) praktycznie brak możliwości korekty poziomu nominalnego kursu po wejściu do ERM II - dozwolona jest tylko rewaluacja parytetu centralnego.

Ekonomiści nie mają raczej wątpliwości, że w systemie ERM II powinniśmy być możliwe najkrócej, aby nie narażać się zbyt długo na wspomniane wyżej ryzyko.

Biorąc pod uwagę strategię polityki pieniężnej NBP i kryterium inflacyjne z Maastricht, wysokość rynkowej stopy nie powinna stanowić przeszkody w wejściu do euro. Jeśli na odpowiednim poziomie ustabilizowana będzie inflacja i kurs walutowy, stopy procentowe w naturalny sposób dostosują się do wysokości, która zapewni wypełnienie kryterium.

Oczywiście wymagana jest przy tym rozsądna polityka fiskalna, bo pamiętajmy, że wskaźnikiem rynkowych stóp procentowych jest rentowność 10-letnich obligacji skarbowych, więc możliwe są takie sytuacje jak obecnie w Grecji, tj. kombinacje bardzo niskiej inflacji $(0,1 \%)$ i wysokich stóp procentowych, które rynek wycenia na ponad 20\%. Największym wyzwaniem dla Polski w wypełnieniu kryteriów z Maastricht jest konieczność ograniczenia nierównowagi fiskalnej do poziomu poniżej 3\% PKB.

Trudność dostosowania fiskalnego w naszych warunkach wynika nie tyle z poziomu nierównowagi fiskalnej, ile z charakteru naszego systemu finansów publicznych, które cechują się strukturalnym deficytem - nawet w roku 2007, kiedy wzrost gospodarczy sięgał 7\%, system finansów publicznych wykazywał deficyt. Dostosowanie fiskalne, jakie odbywa się w Polsce od roku 2010, jest, po pierwsze, niewystarczające z punktu widzenia spełnienia kryterium - a rządowy program konwergencji zakładał, że na koniec roku 2012 deficyt wyniesie 2,9\% PKB, podczas gdy faktycznie wyniósł 3,9\% PKB.

Po drugie, stosunkowo proste i ,bezbolesne" środki ograniczania nierównowagi fiskalnej (np. zmniejszenie transferu składki do OFE od roku 2011) zostały praktycznie

${ }^{2}$ Problem, o którym jest mowa ma dwa aspekty, pierwszy z nich to, że Słowacja weszła do strefy euro po kursie około 3 zł 20 gr. Polski złoty w 2009 r. osłabł po spekulacjach giełdowych do 4,90 zł za 1 euro i złotówka stała się bardziej konkurencyjna w polskim eksporcie. Takie wahania waluty mogą być demoralizujące dla eksporterów, ponieważ bez konkurencji i podniesienia jakości swoich towarów otrzymują za swój niezmieniony towar więcej złotówek. Drugi aspekt to, że w tym samym czasie import w Polsce był znacznie droższy, w tym kupowanie nowych technologii, towarów konsumpcyjnych, surowców itd., itp. Osłabienie waluty przełożyło się na niższe pensje i emerytury, Polacy dużo więcej płacili za benzynę, zagraniczne wczasy. W dłuższym czasie Słowacja wygrała, dla Słowaków wprowadzone przed pięcioma laty euro miało znaczenie prestiżowe, a gospodarka zyskała. Inwestycje zagraniczne w ciagu dwóch pierwszych lat obowiązywania nowej waluty wzrosły ze 123 do 518 mln euro. Obecnie Słowacy bez kompleksów jeżdżą do Wiednia, Pragi i Budapesztu, nie czują się jak biedacy zza żelaznej kurtyny, ale jak normalni sąsiedzi. Co więcej dzięki bardzo dobrej polityce premiera Roberta Fico, ceny po akcesji do euro nie poszły w górę (Wołos, Grzesiczak, 2014). 
wyczerpane. Zabiegi księgowe, takie jak zapisanie w budżecie na rok 2013 pożyczki z budżetu państwa dla Funduszu Ubezpieczenia Społecznego (pożyczka, w przeciwieństwie do dotacji, nie jest wydatkiem, więc nie zwiększa deficytu budżetu państwa), nie mają znaczenia dla systemu ESA'95, a to według tej statystyki jest oceniany stan finansów publicznych krajów UE.

Po trzecie, sytuacja demograficzna i zobowiązania prawne państwa znacznie ograniczają pole do zmniejszania wydatków. Wobec faktu, że wydatki sztywne w budżecie państwa sięgają $80 \%$, praktycznie jedyną możliwością zmniejszania wydatków publicznych jest ograniczanie inwestycji, co faktycznie następuje od roku 2011, ze swoimi negatywnymi skutkami dla wzrostu gospodarczego.

Po czwarte, kształtowanie się dynamiki podstawowych wielkości makroekonomicznych utrudnia spełnienie kryterium fiskalnego. Słabnący przyrost PKB zmniejsza wpływy podatkowe i zwiększa presję na wydatki społeczne (zasiłki dla bezrobotnych, pomoc społeczna, „uciekanie" na rentę przed bezrobociem), a szybko spadająca inflacja zmniejsza nominalną wartość PKB, więc w tym samym czasie rośnie licznik (deficyt) i maleje mianownik (nominalny poziom $\mathrm{PKB}$ ) - relacja deficytu do PKB się zwiększa. Dyskusja powinna więc przede wszystkim dotyczyć nie tego, czy zmniejszyć nierównowagę w finansach publicznych, ale jak to robić i w jakim czasie, by nie osłabiało to dynamiki gospodarczej.

Bardzo wiele wskazuje, że przyjęcie euro niesie poważne korzyści dla polskiej gospodarki, takie jak ograniczenie ryzyka kursowego, zmniejszenie kosztów transakcyjnych czy uzyskanie większego wpływu na funkcjonowanie instytucji UE. Należy jednak pamiętać, że pozbycie się złotego na rzecz euro z pewnością nie zapewni automatycznie szybkiego, stabilnego rozwoju, a rezygnacja $\mathrm{z}$ narodowej waluty rodzi kilka zasadniczych wyzwań, takich jak:

1) wybór optymalnego poziomu kursu walutowego, po którym wymienimy złote na euro, co określi poziom konkurencyjności polskiej gospodarki;

2) niebezpieczeństwo realnej aprecjacji kursu na skutek podwyższonej inflacji po wejściu do strefy euro, co wymagać będzie utrzymania szybkiego tempa przyrostu wydajności pracy, aby uniknąć utraty konkurencyjności;

3) konieczność prowadzenia rozważnej polityki makroostrożnościowej, zapobiegającej powstawaniu baniek spekulacyjnych;

4) uniknięcie uciążliwych skutków wypełnienia nominalnych kryteriów konwergencji, wynikających m.in. z konieczności czasowego usztywnienia kursu walutowego oraz ograniczenia nierównowagi fiskalnej (Tomkiewicz, 2013, s. 4).

W aktualnej sytuacji gospodarczej i lat zaniechania reform gospodarki Polska nie jest obecnie gotowa na przyjęcie euro, ponieważ nie wypełnia żadnego z kryteriów konwergencji nominalnej (znanych też jako kryteria z Maastricht), o czym informują dane zaprezentowane w tabeli 1 . Ponadto wprowadzenie wspólnej waluty najpewniej wymagałoby zmian w Konstytucji RP ${ }^{3}$.

\footnotetext{
${ }^{3}$ Jest to problem natury politycznej i sporu rządu z eurosceptyczną opozycją, która uważa, że przyjęcie wspólnej waluty ogranicza suwerenność Polski. Samo wstapienie Polski do UE, było zobowiązaniem do przyjęcia euro w przyszłości przez nasz kraj. Wchodząc do Unii Polska przeprowadziła referendum akcesyjne łącznie z zapowiedzią przyjęcia wspólnej waluty euro (zgodnie z art. 4 traktatu akcesyjnego) większość społeczeństwa polskiego opowiedziała się za wstąpieniem. Siła głosowania w referendum jest większa jak w parlamencie.
} 
Tabela 1

Stan wypełnienia przez Polskę kryteriów konwergencji nominalnej w listopadzie 2012 roku

\begin{tabular}{||l|c|c|c||}
\hline \multicolumn{1}{|c|}{ Kryterium } & Wartość referencyjna & $\begin{array}{c}\text { Wartość dla } \\
\text { Polski }\end{array}$ & $\begin{array}{c}\text { Kryterium } \\
\text { wypelnione? }\end{array}$ \\
\hline Kryterium inflacyjne & $2,8 \%$ & $3,9 \%$ & Nie \\
\hline Kryterium fiskalne: & maksymalnie $3,0 \%$ PKB & $5,0 \%$ & Nie \\
\hline deficyt budżetowy & maksymalnie $60,0 \%$ PKB & $56,4 \%$ & \\
\hline dług publiczny & $3,6 \%$ & $5,2 \%$ & Nie \\
\hline Kryterium stopy procentowej & $\begin{array}{c}\text { Polska nie uczestniczy w mecha- } \\
\text { nizmie ERM2 }\end{array}$ & Nie \\
\hline Kryterium kursowe
\end{tabular}

Źródło: J. Gmurczyk, Euro w Polsce. Obawy i pytania, Instytut Obywatelski, 2013/1. Analiza, s. 17.

Rząd polski powinien zadbać, aby przygotowania do przyjęcia wspólnej waluty uwzględniły wdrożenie reform, które pomogłyby przyspieszyć proces realnej konwergencji względem strefy euro i zapewniły Polsce fundamenty rozwoju w łonie europejskiego obszaru walutowego. Szczególnie istotne wydają się takie kroki, jak:

1) wypracowanie strategii rozwoju, której konsekwentna realizacja dążyłaby do podniesienia innowacyjności gospodarki. Chodzi o to, by w Polsce zmniejszyć znaczenie konkurencyjności cenowo-kosztowej na rzecz konkurencyjności pozakosztowej (jakościowej) i tym samym osłabić oddziaływanie ewentualnej aprecjacji realnego efektywnego kursu walutowego na produkcję krajową;

2) obniżka barier działalności gospodarczej. Przedsiębiorstwa prywatne to fundament gospodarki rynkowej, więc im bardziej przyjazne biznesowi otoczenie prawno-administracyjne, tym lepiej dla krajowej konkurencyjności;

3) rozwój zasobu kapitału społecznego, czyli pokładu zaufania i zdolności do współpracy wśród obywateli. Jest to zadanie trudne, ale kluczowe dla utrzymania rozwoju gospodarczego kraju w przyszłości, tj. w horyzoncie polskiej obecności w strefie euro;

4) reforma rynku pracy. Obniżenie wskaźnika bezrobocia wśród osób młodych. Podniesienie efektywności urzędów pracy. Podniesienie pensji minimalnych. Likwidacja umów śmieciowych (to jest demoralizujące);

5) przeciwdziałanie efektom zjawiska starzejącego się społeczeństwa. Dziś w Polsce problem ten nie jest jeszcze odczuwalny, ale z biegiem lat będzie się pogłębiał, wpływając negatywnie na stan finansów publicznych oraz kondycję gospodarki (Gmurczyk, 2013, s. 24-25).

\section{Potencjalne zyski akcesji Polski do strefy euro}

Aby zrealizować cel przyjęcia wspólnej waluty euro, Unia Europejska musi zdobyć poparcie większości społeczeństwa. W Deklaracji z Laeken z grudnia 2001 r. w sprawie przyszłości Unii przedstawiciele państw członkowskich wyrazili przekonanie, że „Wewnattrz Unii musi dojść do przybliżenia instytucji europejskich obywatelom UE". Korzyści ze współpracy międzynarodowej zależą od stanu gotowości społeczeństw krajów członkowskich do poniesienia kosztów, które wynikają ze współpracy (Raport na temat pełnego uczestnictwa Polski..., 2009, s. 79). 
Prawie 10 lat po przystąpieniu Polski do UE, olbrzymia większość Polaków (78\%) akceptuje ten wybór, tylko $15 \%$ jest przeciwnych. Jeszcze kilka lat temu zwolenników było $89 \%$, a przeciwników $5 \%$. Na ten wynik miały wpływ problemy związane z kryzysem gospodarczym w krajach Unii.

Wprowadzenie w Polsce euro przyjmowane jest $\mathrm{z}$ dezaprobata. W ciagu ostatniego półrocza zmniejszył się wprawdzie (o 4 punkty) odsetek przeciwników przyjęcia wspólnej waluty, nadal jednak stanowią oni wyraźną większość (64\%). Euro popiera obecnie $29 \%$ badanych. Co ciekawe, sprzeciw wobec przyjęcia euro jest nie tylko częstszy, ale także bardziej kategorycznie wyrażany niż akceptacja (odpowiedzi zdecydowanie nie są częstsze niż raczej nie, podczas gdy w przypadku deklaracji aprobaty jest odwrotnie).

Największe, sięgające $64 \%$, poparcie dla zastąpienia złotego przez euro odnotowaliśmy w styczniu 2002 roku, przed akcesją Polski do UE. Po wejściu do Unii akceptacja przystapienia naszego kraju do strefy euro słabła. W latach 2007-2008 odsetki zwolenników i przeciwników przyjęcia europejskiej waluty były zbliżone. W pierwszym kwartale 2009 roku, po przystapieniu Słowacji do strefy euro i w okresie dyskusji nad możliwością i zasadnością szybkiego przyjęcia euro przez Polskę, poparcie dla wprowadzenia wspólnej waluty ponownie zwiększyło się do $52-53 \%$. W kolejnych latach, kiedy znane już były problemy finansowe Grecji, a potem innych krajów europejskich, w tym również Polski, akceptacja wprowadzenia wspólnej waluty w naszym kraju zaczęła maleć.

Sprzeciw wobec przystąienia Polski do strefy euro przeważa we wszystkich analizowanych grupach społeczno-demograficznych. Znacząco częściej wprowadzenie euro w naszym kraju popierają mężczyźni (37\%) niż kobiety (22\%). Proporcjonalnie najwięcej zwolenników przyjęcia wspólnej waluty jest wśród mieszkańców ponadpółmilionowych miast (41\%), osób z wyższym wykształceniem (42\%), badanych stosunkowo dobrze sytuowanych - o miesięcznych dochodach per capita powyżej $1500 \mathrm{zł}(40 \%)$, ludzi dobrze oceniających warunki materialne swojego gospodarstwa domowego (38\%). W grupach społeczno-zawodowych do zwolenników wprowadzenia w Polsce euro należą głównie kadra kierownicza i specjaliści (48\%) oraz właściciele firm (46\%).

W elektoratach partyjnych za przystapieniem naszego kraju do strefy euro opowiadaja się najczęściej sympatycy PO oraz Ruchu Palikota. Znacząco więcej niż przeciętnie zwolenników przyjęcia wspólnej waluty jest w elektoracie SLD. Sprzeciw wobec tego projektu wyraźnie dominuje wśród zdeklarowanych wyborców PSL i - przede wszystkim - PiS.

Tabela 2

Czy zgodzil(a)by się Pan(i) na zastąpienie polskiego pieniądza (zlotego) wspólnym dla wielu państw Unii europejskim pieniądzem - euro?

\begin{tabular}{|c|c|c|c|}
\hline \multirow{2}{*}{ Potencjalne elektoraty } & Tak & Nie & Trudno powiedzieć \\
\cline { 2 - 4 } & \multicolumn{3}{|c|}{ w \% } \\
\hline RP* & 52 & 45 & 3 \\
\hline PO & 49 & 46 & 5 \\
\hline SLD & 45 & 55 & 0 \\
\hline PSL & 32 & 59 & 5 \\
\hline PiS & 20 & 75 & 9 \\
\hline
\end{tabular}

* Dane dotyczące zwolenników Ruchu Palikota należy interpretować ostrożnie ze względu na ich niewielką liczbę w badanej próbie. 
Stosunek do przyjęcia przez Polskę wspólnej waluty wiąże się z oceną perspektyw, jakie rysują się przed eurolandem. Osoby przekonane, że w najbliższych latach strefa euro rozszerzy się o kolejne państwa, w większości popierają wprowadzenie wspólnej waluty. Niechętna temu posunięciu jest natomiast zdecydowana większość respondentów, którzy sądzą, że w najbliższych latach strefa euro nie będzie się rozszerzać lub że się skurczy, oraz - przede wszystkim - ci, którzy przewidują jej całkowity rozpad (Wójcik, 2012).

Zdecydowana większość osób przekonanych o zasadności przyjęcia wspólnej waluty sądzi, że nie należy się z tym spieszyć. Tego zdania jest blisko cztery piąte zwolenników przyjęcia euro (79\%). Za możliwie najszybszym wprowadzeniem w Polsce euro opowiada się 17\% respondentów popierających tę decyzję (Badara, Roguska, 2013).

Zarówno zwolenników, jak i przeciwników przyjęcia przez Polskę wspólnej waluty, poproszono o uzasadnienie swojego stanowiska. Badani odpowiadali na pytania otwarte, a zatem nie korzystali z gotowej kafeterii odpowiedzi, ale samodzielnie formułowali argumenty za i przeciw wprowadzeniu euro.

Zwolennicy przyjęcia przez Polskę europejskiej waluty odwoływali się do dwojakiego rodzaju uzasadnień. Po pierwsze, wymieniali przewidywane korzyści związane z przyjęciem euro, po wtóre, wskazywali na szerszy europejski kontekst tej decyzji.

Najczęściej przywoływanym argumentem na rzecz wprowadzenia euro w Polsce jest wygoda i ułatwienia związane ze wspólną walutą. Wśród przewidywanych pozytywnych skutków przyjęcia euro dla poszczególnych dziedzin życia wymieniano przede wszystkim korzyści dla gospodarki i przedsiębiorców: ułatwienie współpracy gospodarczej z innymi krajami, wymiany handlowej, poprawę sytuacji ekonomicznej kraju. Wielu zwolenników wprowadzenia euro wskazywało na korzyści finansowe z tym związane, argumentując m.in., że euro jest bardziej stabilną, silniejszą walutą niż złoty, że będziemy mniej narażeni na spekulacje walutowe i generalnie wyeliminowany zostanie problem ryzyka kursowego. Stosunkowo dużo osób zadeklarowało, że spodziewa się wyższych dochodów (zarobków, emerytur) i ogólnie poprawy warunków życia, niektórzy liczą nawet na wyrównanie poziomu życia w Polsce i krajach unijnych po wprowadzeniu euro. Wśród najczęściej wymienianych pozytywnych skutków przyjęcia wspólnej waluty znalazły się także korzyści dla podróżujących za granicę, związane z wyeliminowaniem potrzeby wymiany złotego na euro. Część zwolenników przystąpienia Polski do strefy euro wskazywała na korzyści polityczne, jakie odniesie nasz kraj: zyskamy większy wpływ na to, co dzieje się w Europie, nasza pozycja w Unii umocni się, będziemy w głównym nurcie procesu jednoczenia się Europy. Przyjęcie euro jest często przedstawiane jako konsekwencja wejścia Polski do Unii Europejskiej, przy czym na ogół jest ono ujmowane jako naturalne następstwo obecności w UE, rzadziej jako konieczność wynikająca $\mathrm{z}$ zapisów traktatu akcesyjnego. Zgodnie z tym rozumowaniem, skoro jesteśmy w UE, powinniśmy mieć wspólną, obowiązującą w większości państw unijnych, walutę (Eurostat news..., 2013).

Przeciwnicy przystąienia Polski do strefy euro przede wszystkim wskazują możliwe negatywne konsekwencje tej decyzji. Koncentrowali się głównie na społeczno-ekonomicznych skutkach wprowadzenia euro, takich, które będą odczuwalne przez wszystkich obywateli. Mówią przede wszystkim o spodziewanym wzroście cen. Stosunkowo często wyrażano obawy dotyczące zmniejszenia wysokości zarobków oraz rent i eme- 
rytur. Obawy przed obniżeniem osiąganych dochodów wiążą się z podnoszoną wprost przez część osób kwestią kursu wymiany złotego na euro. Niepokój przed wzrostem cen i obniżeniem realnej wartości dochodów znajduje także wyraz w przewidywanym pogorszeniu warunków życia i poszerzeniu zakresu ubóstwa w Polsce. Mniej lub bardziej konkretnie mówiono także o możliwym pogorszeniu sytuacji gospodarczej i sytuacji przedsiębiorstw w naszym kraju: spadku konkurencyjności polskiej gospodarki, braku możliwości korzystania z różnic kursowych, także o przeniesieniu do Polski kryzysu, który dotknął państwa strefy euro. Rzadziej niż kwestie dotyczące społeczno-ekonomicznych skutków wprowadzenia euro, wymieniano możliwe negatywne następstwa polityczne tej decyzji: utratę czy też ograniczenie suwerenności finansowej Polski, brak możliwości prowadzenia własnej polityki w tym zakresie. Część przeciwników przystąpienia do strefy euro obawia się zamieszania i chaosu związanego z tą operacją, trudności z przystosowaniem się do zmian np. ze względu na zaawansowany wiek.

Duża grupa przeciwników wprowadzenia euro argumentowała, że taka decyzja byłaby dziś przedwczesna, bowiem nasz kraj jest nieprzygotowany do przyjęcia wspólnej waluty: nie spełniamy wymogów koniecznych do wprowadzenie euro, różnice w poziomie życia między Polską i krajami Unii są ciagle zbyt duże, a my jesteśmy za biedni, by być członkiem eurolandu.

Część osób odniosła się do zewnętrznych uwarunkowań, które powinny mieć wpływ na decyzję w sprawie przyjęcia euro. Kryzys w państwach strefy euro, niepewna przyszłość wspólnej waluty zniechęcają do jej wprowadzenia.

$\mathrm{W}$ podawanych uzasadnieniach pojawiały się również argumenty natury emocjonalnej. Część osób deklarowała przywiązanie do złotego, powoływała się na patriotyzm, narodową walutę uznawała za symbol polskości (Badora, Roguska, 2013, s. 6-8).

\section{Korzyści z przystąpienia do strefy euro}

Jak wynika z przygotowanego w NBP w 2004 r. Raportu na temat korzyści i kosztów przystapienia Polski do strefy euro, którego aktualność w zasadniczych kwestiach potwierdziły późniejsze publikacje, korzyści z wejścia do eurolandu można podzielić na bezpośrednie oraz długookresowe.

\section{Efekty bezpośrednie}

Zauważalne są zaraz po przyjęciu wspólnej waluty. Są nimi m.in. eliminacja kosztów transakcyjnych i ryzyka kursowego oraz spadek stóp procentowych.

Korzyści z likwidacji kosztów transakcyjnych są tym większe, im więcej jest dokonywanych operacji wymiany waluty krajowej na euro. Wartość tych transakcji jest związana ze stopniem otwartości danej gospodarki, tzn. wielkością jej eksportu oraz importu w relacji do PKB. Polska coraz więcej eksportuje i importuje, dlatego eliminacja kosztów transakcyjnych zyskuje na znaczeniu.

Zniknięcie ryzyka kursowego poprawia warunki prowadzenia działalności gospodarczej. Zmniejsza się niepewność związana z przyszłymi przychodami i kosztami, co 
sprzyja rozwojowi wymiany handlowej. Zmniejsza się także ryzyko inwestycyjne dla inwestorów zagranicznych, którzy nie muszą obawiać się wpływu zmian kursu na koszty prowadzenia działalności (Gmurczyk, 2012).

\section{Efekty długookresowe}

Przyjęcie wspólnej waluty uruchomi przede wszystkim liczne procesy dostosowawcze w gospodarce, których skutki będą odczuwalne w dłuższym okresie.

Do procesów tych zaliczyć należy m.in.:

1) zwiększenie stabilności makroekonomicznej Polski - w oczach inwestorów istotnie wzrośnie nasza wiarygodność, co ograniczy ryzyko występowania gwałtownych przepływów kapitałowych. Może to sprzyjać obniżeniu kosztu pozyskania kapitału przez podmioty gospodarcze i umożliwi polskim przedsiębiorstwom realizowanie przedsięwzięć, które dotychczas napotykały trudności w znalezieniu źródeł finansowania;

2) wzrost efektywności produkcji - stabilne ceny i jednolita waluta zwiększają przejrzystość rynku, a przez to wzmacniają pozycję nabywcy, co poprawia konkurencyjność przedsiębiorstw;

3) wzrost stopy inwestycji - usunięcie niepewności co do kształtowania się kursu walutowego $\mathrm{i}-\mathrm{w}$ konsekwencji - eliminacja premii za ryzyko kursowe prowadzą do spadku stóp procentowych. Tym samym obniża się koszt pozyskania kapitału, co pociaga za sobą wzrost stopy inwestycji krajowych;

4) zwiększony naplyw bezpośrednich inwestycji zagranicznych, za którymi najczęściej napływają nowoczesne technologie i zyskuje się nowe rynki;

5) ożywienie wymiany handlowej;

6) zmniejszenie niepewności dotyczacych skali inflacji i zmian relatywnych cen;

7) integracje finansowa, polegająca na tym, że oddzielne rynki narodowe zaczynają wspólnie funkcjonować jak jeden rynek krajowy. Badania wskazują, że na integracji rynków finansowych najwięcej zyskują kraje o stosunkowo najmniej rozwiniętych rynkach. Dlatego można się spodziewać, że w przypadku Polski korzyści te będą znaczące.

\section{Koszty związane z przystąpieniem do strefy euro}

Za podstawowy koszt przyjęcia euro uznaje się utratę możliwości prowadzenia autonomicznej polityki pieniężnej i kursowej. Polityka prowadzona przez Europejski Bank Centralny (EBC) koncentruje się na całej strefie euro. Oznacza to, że nie zawsze będzie dostosowana do specyficznej sytuacji naszego kraju, zwłaszcza w sytuacji pojawienia się negatywnych skutków wstrząsów czy kryzysów gospodarczych. Negatywne skutki związane z członkostwem w strefie euro zależeć będą w głównej mierze od tego, czy polityka pieniężna EBC okaże się „odpowiednia” z punktu widzenia sytuacji gospodarczej Polski.

Wejście do strefy euro oznacza również przesunięcie ciężaru związanego z przywracaniem i utrzymywaniem równowagi gospodarczej z polityki pieniężnej (np. ustalania 
stóp procentowych) na szerzej zakrojoną politykę finansową. Politykę finansową prowadzi się jednak trudniej niż pieniężną. Instrumenty polityki finansowej mają bowiem wyraźny wpływ na sytuację materialną określonych grup społecznych i zawodowych. Społeczeństwa boją się reform zmierzających do ograniczenia czy racjonalizowania wydatków budżetowych, natomiast rząd i politycy - zwłaszcza w okresie wyborów - nie są skuteczni w przeciwstawianiu się takim oporom.

Innym kosztem związanym z przystapieniem do strefy euro jest konieczność przekazania EBC części rezerw walutowych oraz odejście od płynnego kursu złotego, który zmniejsza prawdopodobieństwo występowania kryzysów i pozwala łagodzić wahania produkcji i zatrudnienia związane $\mathrm{z}$ występowaniem niektórych wstrząsów gospodarczych (Springer, 2007, s. 1-2).

Pewne jest, że korzyści przystąpienia do strefy walutowej euro w przyszłości (dochodzenie do poziomu życia podobnego jak ,starej Unii”) będą większe niż koszty. Dlatego należy dążyć do szybkiego przyjęcia euro.

Argumenty za i przeciw szybkiemu przyjęciu euro

\begin{tabular}{|c|}
\hline \\
\hline Przyspieszenie niezbędnych reform finansów publicznych i rynku pracy \\
\hline $\begin{array}{l}\text { Uniknięcie marginalizacji politycznej wewnątrz UE oraz ryzyka pogorszenia pozycji konkurencyjnej Pol- } \\
\text { ski względem tych krajów, które przystapiły do strefy euro we wcześniejszym terminie }\end{array}$ \\
\hline $\begin{array}{l}\text { Przejściowy charakter korzyści komparatywnych oraz konieczność odejścia od tzw. osłony na opak, jaką } \\
\text { jest aprecjacja waluty krajowej }\end{array}$ \\
\hline Zwiększenie dynamiki inwestycji i wydajności, a dzięki temu trwałe przyspieszenie wzrostu gospodarczego \\
\hline Ożywienie wymiany handlowej ze strefą euro przez wyeliminowanie ryzyka kursowego \\
\hline ęści kosztów transakcyjnych \\
\hline $\begin{array}{l}\text { Zwiększenie porównywalności cen, co wpłynie także na wzmocnienie konkurencji Pozytywna postawa } \\
\text { przedsiębiorców wobec euro }\end{array}$ \\
\hline Argu \\
\hline niezbędnych reform finansów publicz \\
\hline ów związane z wejściem do strefy euro \\
\hline $\begin{array}{l}\text { Możliwość wystąpienia negatywnych skutków dla gospodarki i bilansu płatniczego w wyniku wzmocnie- } \\
\text { nia euro, utrudniającego gospodarce polskiej konkurencję i istotną deprecjację rezerw dewizowych (w ra- } \\
\text { zie mocnego osłabienia dolara) }\end{array}$ \\
\hline $\begin{array}{l}\text { Obawy konsumentów przed wzrostem cen oraz tym, że ich dochody wyrażone w euro byłyby stosun- } \\
\text { kowo niskie. Można je ograniczyć przez wcześniejsze przyzwyczajenie ich do cen wyrażanych w euro } \\
\text { (funkcjonowanie w obrocie cen w dotychczasowej i nowej walucie) oraz przez działania Urzędu Ochrony } \\
\text { Konkurencji i Konsumenta }\end{array}$ \\
\hline kim dokona się zamiana złotego na euro, może być zawyżony (w zwiazzku z napły- \\
\hline $\begin{array}{l}\text { Nasilenie ataków spekulacyjnych na złotego i ich negatywne skutki dla budżetu i gospodarki oraz ko- } \\
\text { nieczność wydłużania terminu przyjęcia euro (w razie niewłaściwego przygotowania się do wejścia do } \\
\text { mechanizmu ERM II) }\end{array}$ \\
\hline \\
\hline
\end{tabular}

Źródło: Z. Szpringer, Dylematy zwiqzane z wejściem..., s. 4.

Wspólna waluta niesie ze sobą liczne korzyści dla osób i firm działających w ramach gospodarki rynkowej. Wspólny pieniądz ułatwia handel i inwestycje, co przyczynia się 
do stworzenia lepszego, bardziej wydajnego systemu podziału pracy. Żeby jednak ten potencjał wykorzystać w pełni wspólna waluta nie może iść w parze z politycznymi naleciałościami w postaci: nadmiernych regulacji gospodarki, inflacyjnej polityki pieniężnej, zwiększonej roli polityki fiskalnej. Wspólnota gospodarcza z jednym pieniądzem powinna charakteryzować się wspólnym rynkiem sprowadzającym się do likwidacji ceł, utrudnień przepływu towarów, usług i pracowników - opierać się na swobodzie ruchu transgranicznego i otwarciu się na handel z krajami spoza strefy (Maciejewicz, 2014).

Alternatywa w postaci zachowania własnego banku centralnego też nie jest satysfakcjonująca. Narodowy Bank Polski wcale nie musi okazać się dla polskich obywateli instytucją bardziej godną zaufania niż Europejski Bank Centralny. Monopol złotego i NBP ma bardzo podobne szkodliwe konsekwencje dla gospodarki co monopol euro i EBC (Sztąberek, 2014).

$$
* * *
$$

Jedna waluta, zacieśnienie więzi gospodarczych, powinno przełożyć się w przyszłości na wspólnotę polityczną. Przyczyniłoby się to przezwyciężenia podziałów unijnych na bogaty Zachód i postkomunistyczny biedny Wschód.

Sukces Europy zależy od możliwości konkurowania gospodarczo-cywilizacyjnego z Azją Wschodnią i Ameryką w skali globalnej. Może się to zmaterializować tylko poprzez utworzenie Federacji Europejskiej, w skład której weszłyby państwa członkowskie Unii. Miałaby ona wspólny rząd, parlament, armię, jednolity system polityczny i gospodarczy. Zlikwidowałoby to istniejący podział na Centrum i Peryferie w obrębie dzisiejszej Unii. Jest to zadanie na miarę XXI wieku dla rządów państw UE, jej elit intelektualnych i przekonania do tego społeczeństw krajów członkowskich.

Polska jest krajem, który mógłby w tej perspektywie wiele wnieść do europejskiej polityki, ale pod warunkiem posiadania odpowiedzialnych elit i wejścia do twardego rdzenia Europy z euro. Unia Europejska będzie konsekwentnie realizować swoje interesy w ramach Eurolandu. Badany problem dotyczy szerszej kwestii, dotyczącej wejścia naszego kraju do Zachodniej cywilizacji europejskiej, do której jako państwo aspirujemy od kilkuset lat. Połączenie się trwałymi więzami ekonomicznymi i politycznymi z tym regionem gwarantuje sukces Polski w teraźniejszości i przyszłości.

\section{Bibliografia}

Badora B., Roguska B. (2013), Komunikat badań CBOS, Bs/42/2013. Obawy i nadzieje $z$ wprowadzeniem euro $w$ Polsce, Warszawa, marzec 2013, http://www.cbos.pl/SPISKOM.PL/2013/k_042_13.PDF.

Beck U. (2013.19.09-24.09), Zwycięstwo markiawelizmu, Polityka.

Eurostat news release (2013), Eurostat nr 4, 8.01.2013, http://epp.eurostat.ec.europa.eu/cache/ITY_ PUBLIC/.

Gmurczyk J. (2012), Ekonomię warto znać, Instytut Obywatelski, 30.08.2012, http://www.instytutobywatelski.p19374/lupa-instytutu/ekonomie-warto-znac. 
Gmurczyk J. (2013), Euro w Polsce. Obawy i pytania, Instytut Obywatelski, 2013/1, Analiza.

Maciejewicz P. (2014), Polityczna wspólna waluta, „Polityka” z dn. 07.03.2014.

Mucha-Leszko B. (2007), Strefa euro, Lublin.

Okręziak L. (2008), Euro - pieniadz międzynarodowy, „Bank i Kredyt”, nr 1.

Orenstein M. A. (2014), Widziane ze Stanów Zjednoczonych. Jak wysoko poleci Polska?, „Gazeta Wyborcza" z dn. 11-12 stycznia.

Raport na temat petnego uczestnictwa Polski w trzecim etapie Unii Gospodarczej i Walutowej, NBP (2009), Warszawa.

Springer Z. (2007), Dylematy zwiqzane z wejściem Polski do strefy euro, „Infos”, nr 14, 10.05.2007, Biuro Analiz Sejmowych.

Sztomberek P. (2014), Czy Polska powinna przystapić do strefy euro?, http://3obieg.pl/czy-polska-powinna-przystapic-strefy-euro.

Tomkiewicz J. (2013), Przyjęcie euro a konkurencyjność gospodarki, „Infos” (BAS), nr 10/147 z 23 maja 2013 r.

Wallerstein I. (2007), Analiza systemów światów. Wprowadzenie, Warszawa.

Wójcik C. (2012), Doceniamy integracje, Instytut Obywatelski, 11.10.2012, http://www.instytutobywatelski.pl/10478/lupa-instytutu/docenimy-integracje.

Wołos D., Grzesicak Ł. (2014), Za koronami nie tęsknia, ,Przegląd”, nr 3 (733) z dn. 13-19.01.2014.

\section{The dilemmas related to launching the euro in Poland in terms of politics and economy}

\section{Summary}

The issue of Poland's accession to the eurozone is universal and crucial both in economic and political terms, as well as with reference to civilizational processes. After the collapse of communism, Poland opted to join European structures (NATO and the European Union). This choice was concordantly made by the political elite, and the entire internal and foreign policy of Poland was aimed at these goals, which were eventually achieved in 1999-2004. It might seem that having succeeded there, Poland would continue to integrate with the West and become a part of Western European civilization. This is the only way to escape the peripheries and take a central position in Europe and western civilization, something Poland has unavailingly endeavored to achieve for centuries. It has turned out, however, that on account of opportunistic and short-term gains the majority of the political elite have changed their standpoint on this fundamental issue. This political trend is quite dangerous as it may result in the Polish state and society being marginalized on the peripheries of European circles. The euro is more than a single currency, it is also a guarantee of Poland's permanent position in the center of Europe, that could ensure secure its existence, its present and future economic stability, and liberation from its Eastern European past.

Key words: euro, European structures, center and peripheries, hard core of Europe, Western European civilization 